\title{
Synthesis and Evaluation of Some Oxime Esters as New Attractants for Cockroaches
}

\author{
Abdulraman Oiza Chogudo Aliyu*, Joseph Abiodun Dauda, Rotimi Larayetan \\ Chemistry Department, Kogi State University, Anyigba, Kogi State
}

*Corresponding Author: Abdulraman Oiza Chogudo Aliyu, Chemistry Department, Kogi State University, Anyigba, Kogi State

\begin{abstract}
Six oxime esters were synthesised and tested for their effectiveness as attractants of Periplaneta Americana cockroaches in the laboratory by the choice chamber method. The oxime esters of cinnamaldoxme, crotonaldoxime and vanilyl oxime formed from palmitoyl and oleoyl chlorides were found to be effective attractants for P. americana cockroaches. The receptor model proposed by others is used to explain this effectiveness.
\end{abstract}

Key words: Oxime esters, Synthesis, Cockroach, attractants, P. Americana, Evaluation

\section{INTRODUCTION}

Cockroaches are disease causing agents. They are known to be carriers of protozoan, bacterial, helminth and viral diseases (Pandey et al, 1994). A study by Fakoorziba, et al (2010), isolated twenty five (25) different species of medically important bacteria with 22 of them Gram negative bacteria from $P$. americana and $B$. germanica. It has been found that $P$. americana may also play a role in the transmission of E. tenella among chicken and between chicken flocks (Jarujareet et al, 2019).

Many insecticides can kill Cockroaches but their toxicities are undesirable in domestic environments hence the need for substances and agents that are more environmentally tolerable for control of the pest.

Earlier studies on the use of attractants for the control of cockroaches were mainly by Sugarawa et al $(1975,1976)$. They concluded that propyl 2-cyclohexyl acetate (Fig. 1.)was the best attractant based on a receptor model in which a six-atom straight chain with no branch acts as the tail with a cyclohexane ring serving as the head. According to Sugarawa et al (1975), introduction of unsaturation in the ring or a methylene group in the tail brought down the activity of the molecules

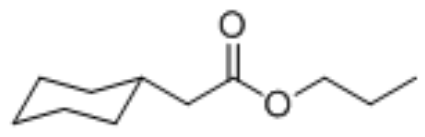

Fig1. Propyl 2-cyclohexylacetate

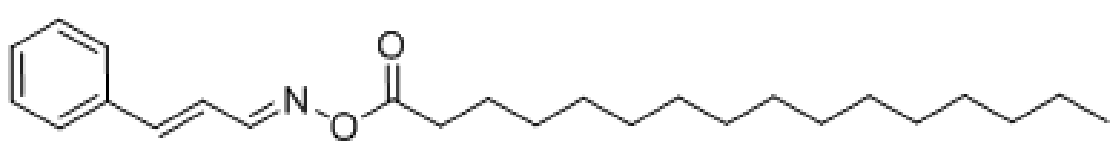

Fig2. (1E, 2E)-cinnamaldehyde O-palmitoyl oxime

Upon close inspection, apart from the ester functional group in the middle where there is a dipole with carbonyl carbon as the positive end, the two ends of the molecule (on either side of the ester functional group) are hydrophobic. With the desire to design a molecule that is more environmentally friendly, we came up with a molecule with the oxime ester functional group but with both ends as fragments from naturally occurring compounds such as the structures shown below (See Table 1.) in which the oxime esters are formed by the reaction of cinnamaldoximes, crotonaldoximes and vanillyl oximes with oleoyl and palmitoyl chlorides. We were curious to see the effect of added nitrogen atom, unsaturated head as well as the much longer alkyl chain on attraction activity. 


\section{MATERIALS AND MeTHODS}

Oleoyl and palmitoyl chlorides were obtained from Sigma-Aldrich. The oximes were prepared according to literature methods (Aliyu et al, 2011a, 2011b and 2011c). The infrared spectra were recorded on a Perkin-Elmer Model 1310 spectrophotometer while the ${ }^{1} \mathrm{H}$ and ${ }^{13} \mathrm{CNMR}$ spectra were run at $250 \mathrm{MHz}$ (Bruker dpx $250 \mathrm{MHz}$, PROBHD $5 \mathrm{~mm}$ Dual 13, Solvent: $\mathrm{CDCl}_{3}$, Cardiff University of Wales, U.K.).

\subsection{General Method for Preparation of Oximes}

A mixture of redistilled aldehyde, $9.43 \mathrm{~g}(0.0714 \mathrm{~mol})$; hydroxyl amine hydrochloride. $4.97 \mathrm{~g}(0.0715$ mol); triethyl amine, $7.24 \mathrm{~g}, 11.0 \mathrm{~mL}(0.0715 \mathrm{~mol})$ dissolved in methanol $(100 \mathrm{~mL})$ in a three-necked $250 \mathrm{~mL}$ round bottomed flask equipped with a reflux condenser was heated at reflux for 1 hour. Methanol was removed by distillation and the cooled residue washed once with cold water. Recrystallization was done with dilute ethanol.

The compounds were converted to the various oxime esters by the following procedures.

\subsubsection{Cinnamaldoximyl palmitate (O-palmitoyl cinnamaldoxime ether)}

Cinnamaldoxime, $5.0 \mathrm{~g}(0.034 \mathrm{~mol})$, palmitoyl chloride, $10.32 \mathrm{~mL}(0.034 \mathrm{~mol})$ and potassium carbonate, $4.62 \mathrm{~g}(0.034 \mathrm{~mol})$ were mixed together in acetone $(100 \mathrm{~mL})$ in a $250 \mathrm{~mL}$ three necked round bottom flask equipped with reflux condenser and a magnetic spin bar. The mixture was stirred for 10 minutes and refluxed for 1 hour. After cooling to room temperature the mixture was poured into cold water $(100 \mathrm{ml})$ and stirred in a $250 \mathrm{~mL}$ beaker. The resulting mixture was suction filtered to obtain a white solid. Yield: $78 \%$. M.p. $110-112^{\circ} \mathrm{C}$. IR ( $\mathrm{cm}^{-1}$, film, $\mathrm{CHCl}_{3}$ ): 3110-3020 (Ar \& olefinic C-H str.), 28202920 (Methyl and methylene str. $\mathrm{C}-\mathrm{H}), 1740\left(\mathrm{C}=\mathrm{O}\right.$ str.). ${ }^{1} \mathrm{H}-\mathrm{nmr}\left(\mathrm{CDCl}_{3}\right): \delta 0.90\left(\mathrm{t}, 3 \mathrm{H}, \mathrm{CH}_{3}\right), 1.40$ (sextet, $2 \mathrm{H}, \mathrm{CH}_{2}$ ), 1.35 (quintet, $22 \mathrm{H}, \mathrm{CH}_{2}$ ), 1.65(quintet, $2 \mathrm{H}, \mathrm{CH}_{2}$ ), 2.02(t, $2 \mathrm{H}, \mathrm{O}=\mathrm{CCH}_{2}$ ), 6.70$6.80(\mathrm{~m}, 2 \mathrm{H}, \mathrm{CH}=\mathrm{CH}), 7.10-7.40(\mathrm{~m}, 3 \mathrm{H}, \mathrm{Ar}-\mathrm{H}), 7.8(\mathrm{~d}, J=12.5 \mathrm{~Hz}, 1 \mathrm{H}, \mathrm{N}=\mathrm{CH}) ;{ }^{13} \mathrm{C}-\mathrm{NMR}\left(\mathrm{CDCl}_{3}\right)$ $\delta 168.7,153.8,151,149,127,123,117,112,56,32$, 29.6. 29.6, 29.6, 29.6, 29.6, 29.6, 29.6, 29.3, $29.3,29.0,25,24.7,22,5,14$

\subsubsection{Cinnamaldoximyl oleate (O-Oleoyl cinnamaldoxime ester)}

The procedure was the same as in O-palmitoyl cinnamaldoxime ether, $5.0 \mathrm{~g}(0.034 \mathrm{~mol})$, oleoyl chloride, $10.234 \mathrm{~g}$ or $11.25 \mathrm{~mL}(0.034 \mathrm{~mol})$ and potassium carbonate, $4.62 \mathrm{~g}(0.034 \mathrm{~mol})$ were mixed together in acetone $(100 \mathrm{~mL})$. Yield: $12.0 \mathrm{~g}, 85 \%$; white solid, m.p., $118-121^{\circ} \mathrm{C}$. IR $\left(\mathrm{cm}^{-1}\right.$, film, $\left.\mathrm{CHCl}_{3}\right)$ : 3010-3020(Ar \& olefinic C-H str.), 2820-2920(methyl and methylene str. C-H), 1740(C=O str.). ${ }^{1} \mathrm{H}-$ $\mathrm{nmr}\left(\mathrm{CDCl}_{3}\right): \delta 0.9\left(\mathrm{t}, 3 \mathrm{H}, \mathrm{CH}_{3}\right), 1.35$ (quintet, $\left.14 \mathrm{H}, \mathrm{CH}_{2}\right), 1.40\left(\mathrm{~m}, 6 \mathrm{H}, \mathrm{CH}_{2}\right), 1.65$ (quintet, $3 \mathrm{H}, \mathrm{CH}_{2}$ ), $2.20(2 \mathrm{qs}, 4 \mathrm{H}$, allylic $\mathrm{H}), 2.35\left(\mathrm{t}, 2 \mathrm{H}, \mathrm{CH}_{2}\right), 5.30(\mathrm{q}, 1 \mathrm{H}, \mathrm{CH}), 5.7(\mathrm{q}, 1 \mathrm{H}, \mathrm{CH}), 6.70-6.80(\mathrm{~m}, 2 \mathrm{H}$, $\mathrm{CH}=\mathrm{CH}), 7.10-7.40(\mathrm{~m}, 5 \mathrm{H}, \mathrm{ArH}), 7.8(\mathrm{~d}, \mathrm{~J}=12.5 \mathrm{~Hz}, 1 \mathrm{H}, \mathrm{N}=\mathrm{CH}) .{ }^{13} \mathrm{C}-\mathrm{nmr}\left(\mathrm{CDCl}_{3}\right): \delta 177.0,163.7$, 131.7, 140.1, 134.9, 130.2, 128.4, 127.7, 126.2, 120.6, 33.6, 33.4, 32.5, 31.2, 30.8, 30.6, 30.5, 30.4, $30.3,30.1,30.0,29.7,25.1,23.1,14.0$.

\subsubsection{Crotonaldoximyl palmitate (O-palmitoyl crotonaldoxime ester)}

Procedure was the same as for O-oleoyl cinnamaldoxime ether except that crotonaldoxime, $2.89 \mathrm{~g}$ $(0.034 \mathrm{~mol})$, palmitoyl chloride, $10.32 \mathrm{~mL}(0.034 \mathrm{~mol})$ and potassium carbonate, $4.62 \mathrm{~g}(0.034 \mathrm{~mol})$ were dissolved in acetone, $100 \mathrm{~mL}$. Yield: $8.10 \mathrm{~g}(74 \%)$; white solid, m.p. $101^{\circ} \mathrm{C}$. IR( $\mathrm{cm}^{-1}$, film, $\left.\mathrm{CHCl}_{3}\right)$ : 3010-3020 (Olefinic C-H str.), 2820-2920(methyl and methylene str. C-H), $1740\left(\mathrm{C}=\mathrm{O}\right.$ str.). ${ }^{1} \mathrm{H}-$ $\mathrm{NMR}\left(\mathrm{CCl}_{4}\right): \delta 0.9\left(\mathrm{t}, 3 \mathrm{H}, \mathrm{Me}\right.$ ); 1.30 (quintet, $\left.24 \mathrm{H}, \mathrm{CH}_{2}\right), 1.65$ (quintet, $\left.2 \mathrm{H}, \mathrm{CH}_{2}\right), 1.90(\mathrm{Dd}, J=7 \mathrm{~Hz}$, $\left.3 \mathrm{H}, \mathrm{CH}_{3}\right), 2.40\left(\mathrm{t}, 2 \mathrm{H}, \mathrm{OC}-\mathrm{CH}_{2}\right) ; 5.0(\mathrm{~m}, 1 \mathrm{H},=\mathrm{CH}-), 5.8(\mathrm{~m}, 1 \mathrm{H}, \mathrm{CH}=) ; 7.9(\mathrm{~d}, 1 \mathrm{H}, \mathrm{N}=\mathrm{CH}) .{ }^{13} \mathrm{C}-\mathrm{NMR}$ $\left(\mathrm{CDCl}_{3}\right): \delta 174.0,163.7,137.0,124.2,34.16,32.12,29.90,29.88,29.82,29.78,29.70,29.68,29.66$, 29.56, 29.47, 29.37, 25.13, 22.84, 17.50, 14.13.

\subsubsection{Crotonaldoximyl oleate}

The procedure was the same as for crotonaldoxime palmitate except that crotonaldoxime, $2.89 \mathrm{~g}$ $(0.034 \mathrm{~mol})$, oleoyl chloride, $11.25 \mathrm{~mL}(0.034 \mathrm{~mol})$ and potassium carbonate, $4.62 \mathrm{~g}(0.034 \mathrm{~mol})$ were dissolved in acetone, $100 \mathrm{~mL}$. After work-up, Yield: $9.8 \mathrm{~g}(82 \%)$ yellow solid, m.p. $112^{\circ} \mathrm{C}$. IR $\left(\mathrm{cm}^{-1}\right.$, film, $\mathrm{CHCl}_{3}$ ): 3010-3020 (Olefinic C-H str.), 2820-2920(methyl and methylene str. $\left.\mathrm{C}-\mathrm{H}\right), 1740(\mathrm{C}=\mathrm{O}$ str.). ${ }^{1} \mathrm{H}-\mathrm{NMR}\left(\mathrm{CCl}_{4}\right): \delta 0.9$ (t, $3 \mathrm{H}, \mathrm{CH}_{3}$ ); 1.35 (quintet or m, $20 \mathrm{H}, \mathrm{CH}_{2}$ ), 1.60 (quintet, $2 \mathrm{H}, \mathrm{CH}_{2}$ ), 2.18 (Dd, $J=7 \mathrm{~Hz}$ and $\left.J=1 \mathrm{~Hz}, 3 \mathrm{H}, \mathrm{CH}_{3}\right), 2.25(\mathrm{~m}, 4 \mathrm{H}$, allylic $\mathrm{H}), 2.35\left(\mathrm{t}, 2 \mathrm{H}, \mathrm{OC}_{-} \mathrm{CH}_{2}\right) ; 5.0(\mathrm{~m}, 1 \mathrm{H},=\mathrm{CH}-)$, 
$5.3(\mathrm{~m}, 2 \mathrm{H}, \mathrm{CH}=\mathrm{CH}), 5.8(\mathrm{~m}, 1 \mathrm{H}, \mathrm{CH}=) ; 7.9(\mathrm{~d}, 1 \mathrm{H}, \mathrm{N}=\mathrm{CH}) .{ }^{13} \mathrm{C}-\mathrm{NMR}\left(\mathrm{CDCl}_{3}\right): \delta 173.2,163.7,143.0$, $130.5,130.2$, 34.10, 32.64, 32.0, 31.94, 29.69, 29.61, 29.53, 29.35, 29.22, 29.16, 29.09, 28.99, 24.88, $22.71,17.5,14.13$.

\subsubsection{Vanilinoximyl palmitate}

The procedure was the same as for crotonaldoxime oleate except that vaniline oxime, $5.70 \mathrm{~g}$ $(0.034 \mathrm{~mol})$, palmitoyl chloride, $10.32 \mathrm{~mL}(0.034 \mathrm{~mol})$ and potassium carbonate, $4.62 \mathrm{~g}(0.034 \mathrm{~mol})$ were dissolved in acetone. Yield:11.18g $(81 \%)$, yellow solid, m.p.: $138-40^{\circ} \mathrm{C}$. IR $\left(\mathrm{cm}^{-1}\right.$, film, $\left.\mathrm{CHCl}_{3}\right)$ : 3110-3020 (Ar-H \& olefinic C-H str.), 2820-2920 (Methyl and methylene str. C-H), 1740 (C=O str.), 3540 (O-H str.), 1268 (MeO- C-H str). ${ }^{1} \mathrm{H}-\mathrm{nmr}\left(\mathrm{CDCl}_{3}\right): \delta 0.90$ (t, 3H, $\left.\mathrm{CH}_{3}\right), 1.30-1.35$ (quintet, $24 \mathrm{H}$, $\mathrm{CH}_{2}$ ), 1.65(quintet, $\left.2 \mathrm{H}, \mathrm{CH}_{2}\right), 2.02\left(\mathrm{t}, 2 \mathrm{H}, \mathrm{OCCH}_{2}\right), 7.10-7.40(\mathrm{~m}, 3 \mathrm{H}, \mathrm{Ar}-\mathrm{H}), 7.8(\mathrm{~s}, J=12.5 \mathrm{~Hz}, 1 \mathrm{H}$, $\mathrm{N}=\mathrm{CH}) ;{ }^{13} \mathrm{C}-\mathrm{NMR}\left(\mathrm{CDCl}_{3}\right) \delta 169.0,154.0,151.0,149.0,127.0,123.0,117.0,112.0,56.0,32.0,32.0$, 29.6, 29.6, 29.6, 29.6, 29.6, 29.6, 29.6,29.3, 29.3, 29.0, 25.0,22.7, 14.0.

\subsubsection{Vanilinoximyloleate}

The procedure was the same as for Vanilinoximyl palmitate except that vaniline oxime, $5.70 \mathrm{~g}$ $(0.034 \mathrm{~mol})$, oleoyl chloride, $10.32 \mathrm{~mL}(0.034 \mathrm{~mol})$ and potassium carbonate, $4.62 \mathrm{~g}(0.034 \mathrm{~mol})$ were dissolved in acetone. Yield:12.30g (84\%), yellow solid, m.p.: $135-138^{\circ} \mathrm{C}$. IR $\left(\mathrm{cm}^{-1}\right.$, film, $\left.\mathrm{CHCl}_{3}\right)$ : 3110-3020 (Ar-H \& olefinic C-H str.), 2820-2920 (Methyl and methylene str. C-H), 1740 (C=O str.), 3540 (O-H str.), 1268 (MeO- C-H str). ${ }^{1} \mathrm{H}-\mathrm{nmr}\left(\mathrm{CDCl}_{3}\right): \delta 0.90$ (t, $3 \mathrm{H}, \mathrm{CH}_{3}$ ), 1.40 (sextet, $2 \mathrm{H}, \mathrm{CH}_{2}$ ), 1.30 (quintet, $\left.18 \mathrm{H}, \mathrm{CH}_{2}\right), 1.60$ (quintet, $\left.2 \mathrm{H}, \mathrm{CH}_{2}\right), 2.20\left(\mathrm{t}, 2 \mathrm{H}, \mathrm{OC}_{-} \mathrm{CH}_{2}\right), 5.30(\mathrm{~s}, 1 \mathrm{H},-\mathrm{OH}), 5.8(\mathrm{~s}, 3 \mathrm{H}$, $\left.\mathrm{CH}_{3} \mathrm{O}-\right), 6.70-6.80(\mathrm{~m}, 2 \mathrm{H}, \mathrm{CH}=\mathrm{CH}), 7.10-7.40(\mathrm{~m}, 3 \mathrm{H}, \mathrm{Ar}-\mathrm{H}), 7.8(\mathrm{~d}, J=12.5 \mathrm{~Hz}, 1 \mathrm{H}, \mathrm{N}=\mathrm{CH}) ;{ }^{13} \mathrm{C}-$ $\operatorname{NMR}\left(\mathrm{CDCl}_{3}\right) \delta 169.0,154.0,151.0,149.0,131.0,131.0,127.0,123.0,117.0,112.0,56.0,34.0,34.0$, 32.0, 31.5, 30.0, 29.9, 29.7, 29.7, 29.7, 29.5, 29.3, 29.0, 25.0, 23.0, 14.0.

\subsection{Evaluation of Attraction Activity}

\subsubsection{Laboratory Olfactory Bioassay}

The attraction activity of the compounds to olfactory responses of adult male and female as well as nymph of Periplaneta Americana cockroaches were tested with the aid of a choice chamber as previously describe by Pandey, et al,1994. The chamber consists of a central glass Jar connected to two smaller glass jars on two sides by a glass tube $(3.0 \mathrm{~cm}$ diameter) as passage for the cockroaches. Thirty adults (male and female) and fifteen nymphs were placed in the central chamber for one hour before the passages were opened. Fluorescent lights covered with red filtering screens were placed above the olfactometer to facilitate observation in the dark. $5.00 \mathrm{~g}$ of each compound were placed in petri dishes in one of the smaller chambers. An empty petri dish was placed in the second smaller chamber to serve as control. The number of cockroaches entering the chamber with the test compound was counted at intervals of thirty minutes for twelve hours.

The attractant index was deduced according to the method of Randall and Brower (1986).

Attraction index $=(\mathrm{RT}-\mathrm{RU}) /(\mathrm{RT}+\mathrm{RU})$

Where RT = the total number of cockroaches in the treated chamber and RU = the number of cockroaches in the untreated chamber. Each experiment was repeated three times and the average values of attraction index for each compound presented in table1 with a positive value indicating attraction while a negative value represents repellence.

\section{RESULTS}

The attraction index of fresh bread was also determined for comparison to those of the synthesised compounds. Numerous studies have concluded that bread is one of the most attractive food substances for cockroaches (Brenner and Patterson, 1989; Brenner and Pierce, 1991 and Pandey et al, 1994, 1995).

Table1. Attraction index for Oxime esters and fresh bread

\begin{tabular}{|c|c|}
\hline Oxime esters & Attraction index \\
\hline Cinnamaldoximyl palmitate & +0.45 \\
\hline
\end{tabular}




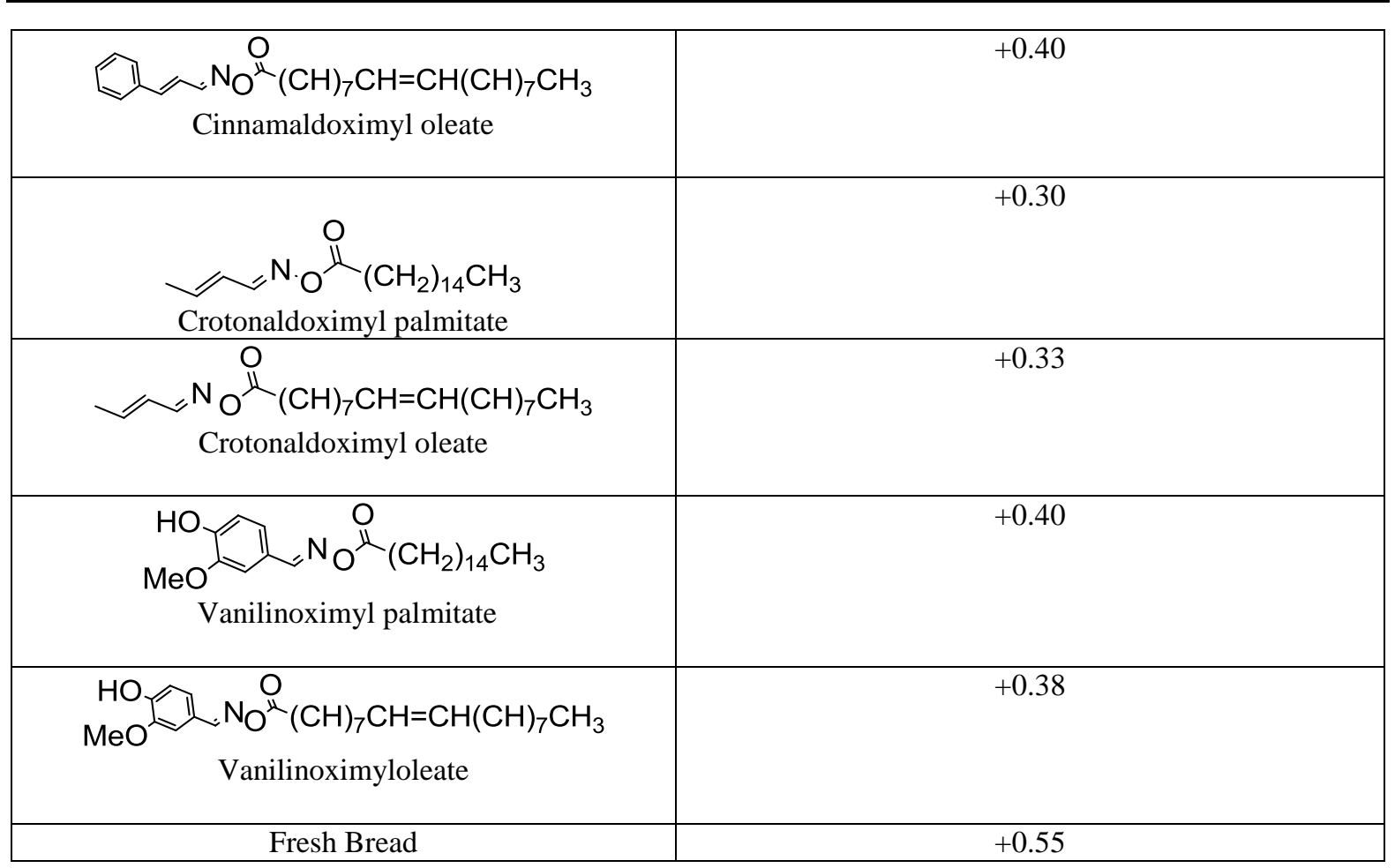

\section{DISCUSSION}

The attraction index of the synthesised compounds compare favourably to that of fresh bread but they are not as attractive. Cinnamaldoximyl palmitate has the highest attractant index among the synthesised compounds. One explanation is that the structure seems to be the best fit for the structureactivity receptor model for carboxylates as predicted by Pandey et al (1994).

This study shows that contrary to the claims of Pandey et al (1994), compounds with molecular weights above 200-214 range are quite capable of attracting cockroaches. However, the attractant activity of these series of compounds (molecular weights between 323-417) might be due to the familiar odour of residual fragments of the parent cinnamaldehyde, vanillin or crotonaldehyde from which they were synthesised. Aromaticity or unsaturation in the head or elongation of the tail chain did not seem to stop the oxime esters from attracting cockroaches.

\section{ACKNOWLEDGEMENT}

The authors are greatful to the entomology laboratory staff of Biological Sciences of Department of Kogi State University, Anyigba for the valuable suggestions.

\section{REFERENCES}

[1] Brenner, R. and Patterson R. S. Laboratory feeding activity and bait preferences of four species of cockroach(Orthoptera: Blattaria). J. Econ. Entomol.1989. 83: 142-147.

[2] Brenner, R. and Pierce, R. R. 1991. Seasonality of peridomestic cockroaches (Blattodea: Blatidae): mobility, winter reduction and effect of traps and baits. J. Econ. Entomol. 1991. 84: 1735-1745.

[3] Fakoorziba, M. R., Eghbal, F., Hassanzadeh, J., Moemenbellah-Fard, M. D. Cockroaches (Periplaneta americana and Blattella germanica) as potential vectors of the pathogenic bacteria found in nosocomial infections. Ann Trop Med Parasitol. 2010 Sep;104(6):521-8.

[4] Jarujareet, W., Kobayashi, M., Taira, K., Ooi, H. K. The role of the American cockroach (Periplaneta americana) as transport host of Eimeria tenella to chickens. Parasitol Res. 2019 Jul;118(7):2311-2315.

[5] Aliyu, A. O. C., Kubmarawa,D. and Barminas, J. T. IR, H-NMR and C13-NMR Characterization of some O-alkyl $\alpha \beta$-unsaturated oxime ethers. International Jour. Chem. Vol. 21, No. 1 (2011) 35-40.

[6] Aliyu, A. O. C., Kubmarawa, D. and Barminas, J. Synthesis and Anti-microbial Activities of some $\alpha, \beta-$ Unsaturated Oxime ethers., Archives of Applied Science Research, 2011, 3 (1):131-138.

[7] Aliyu, A. O. C., Kubmarawa, D., and Barminas, J. Silver Oxide-mediated Oxime Ether Synthesis, Archives of Applied Science Research, 2011, 3 (1):126-130 (

[8] Pandey, K. S.,Shiprakash, K. M. R., Tetrahydropyran Esters as New Attractants for Cockroaches, Biosci. Biotech. Biochem., 58 (4), 647-651, 1994. 
[9] Pandey, K. S., Mendki, M. J., Rao, M. O., and Vaidyanathswamy. 1995. Synthesis and bioevaluation of alicyclic and heterocyclic alkanoates as cockroach attractants. Biosci. Biotech. Biochem. 59: 725 727(1995)

[10] Randall, J. B. and Brower, D. O. A new method to determine repellent, neutral or aggregative properties of chemicals on Blattella Germanica (Dictyoptera: Blattellidae), J. Med. Entomol., 23,251-256 (1986).

[11] Sugarawa, A., Kurihara, S. and Muto, T. Attraction of German cockroaches to cyclohexyl alkanoates and n-alkylcyclohaxane acetates. J. Insect Physiol., 21, 957-964 (1975).

[12] Sugarawa, R., Tominaga, Y. Kobayashi and Muto, T. Effects of side chain modification on the activity of propyl cyclohexaneacetate as an attractant to the German cockroach. J. Insect Physiol. 22: 785-790(1976).

Citation: Abdulraman Oiza Chogudo Aliyu, et.al, "Synthesis and Evaluation of Some Oxime Esters as New Attractants for Cockroaches", International Journal of Advanced Research in Chemical Science, 7(4), pp. 8-12. DOI: https:// doi.org/10.20431/2349-0403.0704002

Copyright: (C) 2020 Authors, This is an open-access article distributed under the terms of the Creative Commons Attribution License, which permits unrestricted use, distribution, and reproduction in any medium, provided the original author and source are credited. 